\title{
DEVELOPMENT OF FUTURE TEACHERS' CRITICAL THINKING THROUGH PEDAGOGICAL DISCIPLINES
}

\section{[ROZVOJ KRITICKEHO MYSLENIA BUDUCICH UCITELOV PROSTREDNICTVOM PEDAGOGICKYCH DISCIPLIN]}

\author{
Sona Grofcikova - Jana Duchovicova - Livia Fenyvesiova
}

doi: 10.18355/PG.2018.7.1.9

\begin{abstract}
The paper deals with critical thinking as a pedagogical-psychological construct; it is focused on definitions and various attributes of critical thinking in pre-graduate students. The accent is put on the possible development of students in teacher training study programmes through selected pedagogical disciplines as the theory of instruction, the theory of education, and didactics of pedagogy. Knowledge of strategies and methods for developing critical thinking is crucial for teacher students, and it is a base for creating own metacognitive skills which lead to critical thinking. There arises an idea that a teacher who is unable to think critically, is also unable to lead even his pupils to critical thinking. Pre-graduate training, next to the other requirements, should be directed to the development of students' critical thinking, and in combination with their quality professional and didactic preparation, it is an assumption for development of competence to think critically in pupils at lower and upper secondary schools.
\end{abstract}

\section{Key words}

critical thinking, metacognition, cognitive skills, pedagogical disciplines

\section{Anotácia}

$\mathrm{V}$ príspevku orientujeme pozornost' na kritické myslenie ako pedagogickopsychologický konštrukt, na jeho vymedzenie a jednotlivé atribúty kritického myslenia u vysokoškolákov. Akcentujeme možnosti jeho rozvoja u študentov učitel'ských študijných programov vo vybraných pedagogických disciplínach ako teória vyučovania, teória výchovy a didaktika pedagogiky. Poznanie stratégií a metód na rozvoj kritického myslenia je pre budúcich učitel'ov základom pre vytvorenie si vlastných metakognitívnych zručností, ktoré vedú ku kritickému mysleniu. Z toho vyplýva téza, že učitel', ktorý nevie kriticky mysliet', nemôže k tomu viest' ani svojich žiakov. Pregraduálna príprava by preto mala smerovat' okrem iného aj $\mathrm{k}$ rozvoju kritického myslenia študentov, čo je $\mathrm{v}$ kombinácii $\mathrm{s}$ kvalitnou odbornou a didaktickou prípravou predpokladom rozvoja kompetencie kriticky mysliet' u žiakov na ZŠ a SS̆.

Kl'účové slová

kritické myslenie, metakognícia, kognitívne zručnosti, pedagogické disciplíny 


\section{Úvod}

Škola ako inštitúcia prechádza mnohými zmenami, ktoré sa zákonite musia odrazit' v ciel'och a obsahu vzdelávania, $\mathrm{v}$ kvalite vzdelávania i v príprave budúcich učitel'ov. $\mathrm{V}$ súčasnom globalizovanom svete postavenom na rýchlosti informácií sa menia požiadavky na vzdelávanie a vzdelanie, ktoré ak chceme byt' progresívni, musíme byt' schopní identifikovat' a implementovat' do nášho systému vzdelávania. Jednou z takýchto výziev súčasnosti je vybavit' žiakov a študentov kompetenciou kriticky a tvorivo mysliet'. Existuje tu potreba kvalitatívnej zmeny z reproduktívneho poznania, vytváraného a osvojovaného cez poznávanie, zapamätávanie a základné pochopenie na produktívne poznanie, pre jednotlivca nové, vytvorené cez analýzu, syntézu, hodnotenie, kreatívne a reflektujúce myslenie (Grofcikova Kozarova, 2017). Rýchlo sa meniaci svet technológií prináša so sebou široko dostupné informácie, preto práve učenie sa prostredníctvom reflektujúceho a kritického myslenia je stratégia ako pracovat's informáciami, akú a ako informáciu použit' zmysluplne (Higgins, 2014). To znamená, že v prvom rade musia byt' učitelia schopní realizovat' kognitívne orientované vyučovanie a implementovat' vyučovacie stratégie pre rozvoj reflektívneho, kritického a tvorivého myslenia žiakov. Kritické myslenie ako konštrukt nadobúda význam vo všetkých akademických disciplínach, ale výnimočné postavenie má $\mathrm{v}$ učitel'skom vzdelávaní. Ked’že každý človek prechádza povinným školským vzdelávaním, tak práve učitelia môžu ovplyvňovat' zručnosti kriticky mysliet' u školopovinnej populácie. Preto musia byt' zdatní $\mathrm{v}$ učebných stratégiách rozvíjajúcich kritické myslenie, riešenie problémov a výkonové zručnosti. Psychodidaktické kompetencie učitela sú schopnosti a zručnosti, ktorými vie spracovat' učivo a riadit' vyučovanie tak, aby rozvíjal (meta)kognitívne procesy žiakov, realizoval vyučovacie stratégie a aktivity hodnotenia, ktoré majú potenciál prispiet' k rozvoju osobnostných a kognitívnych charakteristík žiaka (Duchovicova - Petrova, 2016). V praxi však Williams (2005) upozorňuje, že jednou z najvýraznejších prekážok dosiahnutia tohto ciela a rozvoja psychodidaktických kompetencií v učitel'skom vzdelávaní je limitované poznanie ako podporovat' kritické myslenie.

\section{Metakognícia ako základ kritického myslenia}

Metakognícia pomáha $\mathrm{v}$ rozvoji kritického myslenia tým, že vedie $\mathrm{k}$ používaniu vlastných vedomostí na riadenie a zlepšenie myslenia a učenia sa (Magno, 2010). Zahŕňa aktívnu kontrolu nad kognitívnymi procesmi a poukazuje na vyššie úrovne myslenia (myšlienkové procedúry), jednotlivec je teda schopný kontrolovat', vedome využívat', regulovat' a hodnotit' vlastné mentálne procesy. Metakognícia je schopnost' vidiet' a chápat' zmysel vlastného myslenia. Krykorkova (2008) píše, že prejavmi metakognície sú špecifické vedomosti a zručnosti, ktoré jedincovi umožňujú monitorovat' vlastné kognitívne procesy, kontrolovat' a regulovat' ich. Človek, ktorý má rozvinuté metakognitívne zručnosti učenia sa, odbúrava mechanické učenie sa a využíva aktívne učenie sa.

Jedinec si vytvára rôzne stratégie učenia sa, pričom metakognícia je schopnost' porozumiet' spôsobu vlastného učenia sa a spracovávaniu 
informácií. Vlastné myšlienkové procesy sú ovplyvnené rôznymi faktormi a mat' poznanie (vedomost') o svojom myslení pomáha tomu, aby bol jedinec schopný využit' správnu stratégiu v danom momente. Poznanie viacerých učebných stratégií pomáha v lepšom rozhodovaní sa. Livingstone (1997) na základe prác Flavella uvádza, že metakognitívne poznatky sú základným predpokladom pre reflektovane a strategické učenie sa a možno ich rozčlenit' do troch skupín:

- poznanie seba samého (knowledge of person variables) zahŕn̆a poznatky o vlastnom učení sa a spracovávaní informácii, napr. poznanie vlastných silných a slabých stránok; záujmov; identifikovanie vyučovacieho obsahu (predmetov), ktoré sa človek učí l'ahšie, t’ažšie; preferovanie istých štýlov učenia; poznanie podmienok, za ktorých dosahuje dobré výsledky atd'.;

- poznanie učebných úloh (task variables) zahŕn̆a poznatky o type úloh; o rôznorodosti úloh; o spôsoboch riešenia a požiadavkách na ich riešenie; porozumenie úlohám, zadaniam;

- poznanie stratégií (strategy viariables) zahŕn̆a poznatky o kognitívnych a metakognitívnych stratégiách; o podmienkach použitia stratégie, kedy a kde je vhodné ich použitie.

Používanie pojmov kognitívne a metakognitívne stratégie môže vyvolávat' otázku v čom je medzi nimi rozdiel. Podl’a Livingston (1997) metakognitívne vedomosti nemusia byt' odlišné od kognitívnych vedomostí, rozdiel je v tom, ako informáciu použijeme. Kognitívne stratégie pomáhajú jedincovi dosiahnut' vymedzené ciele (napr. pochopit' text), zatial' čo metakognitívne stratégie sa používajú na zaistenie toho, že ciel' bol splnený (spytovanie seba samého a hodnotenie, či prišlo $\mathrm{k}$ pochopeniu textu). Metakognitívne skúsenosti obvykle predchádzajú alebo nasledujú kognitívnu aktivitu.

\section{Kritické myslenie}

Kritické myslenie je výstupom metakognície. Podl'a Halpern (1999) mysliet' kriticky znamená vyhodnotit' výstupy procesov myslenia, t.j. aká je kvalita riešenia alebo ako dobre je nejaký problém vyriešený. Začína $\mathrm{v}$ momente, ked' sa vyskytne problém a jednotlivec je schopný formulovat' otázky, ktoré ho vedú $\mathrm{k}$ hodnoteniu, argumentovaniu, tvrdeniam a záverom. Zahŕňa riešenie problémov, kalkulovanie pravdepodobností, formulovanie a vyvodzovanie záverov. Kritické myslenie je vedomé preto je možné jeho jednotlivé komponenty nacvičovat', a tým rozvíjat'. Facione a Facione (2008) na základe Delfskej správy definovali kritické myslenie ako proces ciel'avedomého a sebaregulačného usudzovania, dôkladného zvažovania dôkazov, kontextov, konceptualizácie, metód a kritérií. Ako vyplýva z mnohých definícií kritického myslenia, táto vyššia, komplexná kognitívna činnost' je založená na zvládnutí jednoduchších kognitívnych zručností. Podl'a Walker Tileston (2005) sa kritické myslenie vyznačuje nasledovnými zručnost'ami:

- $\quad$ induktívneho myslenia, kde zarad’ujeme napr. príčinu a následok; otvorené problémy, analógie; vyvodzovanie záverov; identifikovanie relevantnosti, vzt’ahov; riešenie problémov; 
deduktívneho myslenia ako využívanie logiky, zdôvodňovania; porozumenie protirečeniam; priestorové problémy; sylogizmy, tvorené sústavou troch výrokov, kde z dvoch predpokladov vyvodíme záver;

- hodnotiaceho myslenia $\mathrm{v}$ podobe rozlišovania faktov a názorov; dôveryhodnosti zdroja; identifikovania hlavných problémov; rozlišovania domnienok; detekcie stereotypov; hodnotenia hypotéz, klasifikovania súboru informácií; predpokladaní dôsledkov; rozhodovania sa; podobnosti a odlišnosti; hodnotenia argumentov.

O kritickom myslení možno uvažovat' aj z pohl'adu dvoch dimenzií (Facione, 2006, 2011, 2013; Halpern, 1999; Williams, 2005).

1. Dimenzia kl'účových kognitívnych zručností (mentálnych spôsobilostí) obsahuje interpretáciu, analýzu, hodnotenie, usudzovanie, vysvetl'ovanie a sebareguláciu (bližšie definované v prácach Facioneho). Tieto zručnosti vedú ku konštruovaniu a hodnoteniu argumentov.

2. Dimenzia osobnostných dispozícii (vlastností, sklonov) je charakterizovaná napr. otvorenost'ou, ochotou vzdat' sa neproduktívnych stratégií myslenia, potláčaním impulzívnej činnosti, zdôraznením skepticizmu v zmysle opytovania sa, spochybňovania. Môžeme sem zaradit' široký okruh záujmov; snahu byt' informovaný; ochotu vziat' do úvahy rôzne alternatívy, hl'adiská a posúdit' zdôvodnenia; opatrnost' pri utváraní záverov; ochotu priznat' si predsudky, stereotypy; ochotu znovu prehodnotit' vlastné stanovisko. Medzi vlastnosti, ktoré reflektujú kritický prístup v myslení možno zaradit' intelektuálnu skromnost', odvahu, empatiu, integritu, vytrvalost', dôveru v rozum, autonómiu.

Podl'a Facione (In Williams, 2005) kognitívne zručnosti kriticky mysliet' a dispozície študentov mierne korelujú a vždy je jedna dimenzia lepšia ako druhá. Napr. môžu inklinovat' ku komplexnému riešeniu problémov a na druhej strane si nevnímat' komplexnost' jednotlivých riešení problému. Pokial' vieme vymedzit' jednotlivé zručnosti reflektované v kritickom myslení, tak potom nevyhnutne vzniká aj otázka ich merania a zist'ovania. U vysokoškolákov sa používa všeobecne uznávaný a štandardizovaný Watson-Glaserov test, pretože sa nevztahuje ku konkrétnym akademickým obsahovým oblastiam, ale vychádza z piatich faktorov myslenia (metakognície), ktoré autori identifikovali ako usudzovanie (schopnost' vyvodit' logický záver zo známych premís), rozpoznanie predpokladov (schopnost' rozoznat' výroky, tvrdenia, ktoré sú posudzované ako pravdivé), dedukciu (schopnost' vyvodzovat', dedukovat' na základe daných tvrdení isté závery), interpretáciu (schopnost' zvažovat' dôkazy a rozhodovanie sa o závere), hodnotenie argumentov (schopnost' rozlišovat' medzi silnými, relevantnými argumentmi) (In Magno, 2010). Ide o meranie schopnosti rozlišovat' existenciu problémov a akceptovat' všeobecnú potrebu dôkazov na podporu pravdy, o meranie poznania platných záverov, abstrakcie a zovšeobecňovania.

Z pohl'adu rozvoja kritického myslenia by bolo vhodné ponúknut' budúcim učitel'om v rámci štúdia i samostatnú disciplínu, ktorá by rozvíjala jednotlivé zručnosti kritického myslenia bez orientácie na konkrétny obsah nejakého akademického predmetu ako to navrhujú Watson a Glaser, ktorí boli za to podrobení kritike. Halpern (1999) však poukazuje na nie celkom oprávnenú 
kritiku tejto myšlienky, že aj vysokoškolskí študenti by mali prechádzat' explicitným vyučovaním ako mysliet'. Lepšie myslenie nie je nevyhnutne výsledkom tradičného, na disciplínach založeného vyučovania, ale domnieva sa, že ak zručnosti kritického myslenia vyučujeme explicitne, priamo pre transfer (napr. prostredníctvom všeobecného kurzu kritického myslenia), využitie početných príkladov $\mathrm{z}$ rôznych disciplín vedie $\mathrm{u}$ študentov $\mathrm{k}$ zlepšeniu ich myslenia vo všeobecnosti tým, že nie je viazané na jeden kontext. Kritické myslenie je komplexná kognitívna činnost' založená na zvládnutí jednoduchších kognitívnych zručností, preto ju považujeme za náročnú. Takéto myslenie si vyžaduje čas na zvládnutie, jeho rozvoj a zlepšovanie je podmienené teoretickým poznaním a praktickým nacvičovaním (Van Gelder, 2005). Halpern (1999) doplňa, že kritické myslenie je viac ako len správne využitie istej zručnosti vo vhodnom kontexte. Je to schopnost' a dispozícia človeka rozoznat' kedy je použitie zručnosti potrebné a ochota vyvinút isté mentálne úsilie na jej použitie. Ako sme spomenuli vyššie, nemôžeme očakávat', že zručnosti kritického myslenia osvojené v jednej situácií budú automaticky, spontánne použité v iných situáciách, preto je nutné pomôct' študentom učitel'ských študijných odborov rozvíjat' si teoretické pochopenie a poznanie ako východisko pre transfer do praktickej činnosti.

\section{Stratégie rozvíjania kritického myslenia v pedagogických disciplínach}

Stratégie predstavujú súbor viacerých postupov a metód, ktoré vedú $\mathrm{k}$ dosiahnutiu ciel'ov $\mathrm{v}$ nejakej oblasti. Z pohl'adu budúcich učitel'ov je nevyhnutné poznat' také učebné stratégie, ktoré možno efektívne využit' $\mathrm{v}$ rôznych študijných odboroch a vyučovacích predmetoch. Petrova a Kozarova (2017) popisujú štyri kategórie učebných stratégií, ktoré sa vzájomne podmieňujú:

- kognitívne stratégie, medzi ktoré zarad’ujú napr. mentálne mapovanie, štruktúrovanie a organizovanie učiva;

- metakognitívne stratégie ako monitorovanie, plánovanie, regulovanie pozornosti pri učení, modifikovanie učebného prostredia;

- motivačné stratégie $v$ podobe podpory vonkajšej a vnútornej motivácie, postupov kauzálnej atribúcie, pochopenia významu učiva;

- stratégie sebapoznania, ktoré orientujú pozornost' na poznanie vlastných silných a slabých stránok v učení sa, vhodného učebného štýlu atd’. $\mathrm{Na}$ základe rôznych definícií, vymedzení a štúdií kritického myslenia a rôznych klasifikácií učebných stratégií sme vytvorili dotazník na zist'ovanie poznania a významnosti rôznych stratégií rozvíjania kritického myslenia pre študentov učitel'ských študijných programov. Vymedzili sme si nasledovné oblasti:

- $\quad$ Stratégie na rozvoj sebaregulácie rozvíjajúce osobnostné, vôlové vlastnosti a emócie spojené s kritickým myslením.

- Stratégie na rozvoj systematických a interpretatívnych zručností ako rozpoznanie problému, dôležitých súvislostí a predpokladov $\mathrm{v}$ argumentoch; identifikácia hlavnej, klúčovej myšlienky; triedenie informácií v rozsiahlom odbornom texte; jasné vymedzenie pojmov; parafrázovanie; správna interpretácia údajov. 
- Stratégie argumentácie, predovšetkým identifikácia a rozbor argumentov; určovanie vzt'ahov a súvislostí; podobných a rozdielnych znakov; rozpoznanie tvrdení a dôkazov vargumente; identifikácia nevyjadrených predpokladov; prehodnocovanie vlastných presvedčení; rozlišovanie faktov a domnienok.

- Stratégie pre vyvodzovanie záverov a riešenie problémov ako formulácia alternatívnych návrhov riešení problému; predvídanie dôsledkov; predkladanie záverov, výsledkov; tvorba modelov vyjadrujúcich vzt'ahy medzi premennými; zdôvodňovanie postupov, metodologického prístupu; formulácia argumentov; anticipácia protiargumentov; vyvodzovanie logických záverov z dostupných informácií; vyhodnocovanie spol'ahlivosti dôkazov uvádzaných na podporu tvrdení a dôveryhodnosti autority.

- Stratégie na rozvoj hodnotenia vedúce $\mathrm{k}$ posúdeniu spol'ahlivosti tvrdení a kvality argumentov; hodnoteniu spol'ahlivosti zdroja informácií; identifikácii logických medzier v argumentácii; posúdeniu silných a slabých stránok alternatívnych teórií; hodnoteniu zdôvodnení; efektívnemu rozhodovaniu a riešeniu problémov.

- Stratégie na rozvoj čitatel'ských zručností ako práca s textom, ktorá vedie $\mathrm{k}$ čítaniu s porozumením. V prípade vysokoškolských študentov ide o rozvoj hlbšieho pochopenia odborného textu napr. identifikovaním problémových oblastí, klúčových pojmov; štruktúrovaním textu a určovaním hlavných bodov napr. pomocou osnovy; využitím pojmového mapovania; prepájaním témy s reálnymi edukačnými situáciami; kladením si otázok a hl'adaním odpovedí v texte. (Duchovicova - Tomsik, 2017)

Vymedzené stratégie a v rámci nich jednotlivé postupy a metódy majú svoje miesto vo všetkých pedagogických disciplínach. Poznanie, vytváranie, rozvíjanie a trénovanie zručností kritického myslenia majú v náplni predovšetkým Teória vyučovania, Všeobecná didaktika, Didaktika pedagogiky, kde si študenti učitel'ských študijných programov rozvíjajú teoretické poznanie didaktických konštruktov, ale zároveň si vytvárajú zručnosti analyzovat' priebeh a podmienky vyučovacieho procesu; plánovat', projektovat' a realizovat' vyučovací proces; hodnotit' výstupy a výsledky vzdelávacieho procesu. Ciel’om týchto disciplín je vytvorenie psychodidaktických kompetencií, ktoré vychádzajú zo schopností študentov pracovat' s obsahom vzdelávania a modifikovat' ho; pracovat' s učebnými ciel'mi a úlohami prostredníctvom taxonómií; vyberat' vhodné koncepcie, metódy, postupy, prostriedky vzhl'adom na učebné situácie a podmienky; zavádzat' inovatívne prvky za účelom motivácie a aktivizácie žiakov; reflektovat' svoju činnost', výsledky svojej aj žiackej práce.

Ďalšou skupinou pedagogických disciplín, ktoré ponúkajú priestor pre rozvoj zručností kritického i tvorivého myslenia sú výchovne orientované disciplíny Teória a filozofia výchovy, Teória výchovy a vychovávania, Teoretické základy pedagogiky, ktoré vedú k pochopeniu, interpretácii, diskusii, argumentácii, či hodnoteniu výchovných javov, zákonitostí výchovy a vychovávania, diverzity filozofických a edukačných konceptov, procesuálnej stránky jednotlivých obsahov výchovy. Študenti si postupne utvárajú individuálnu edukačnú koncepciu, ktorú majú príležitost' reflektovat' a modelovat' vo výchovných situáciách počas rôznych typov praxí. 
Výber učebných stratégií musí byt' zámerný pričom študenti pri ich používaní uplatňujú metakognitívnu kontrolu a sebareguláciu (uvedomovanie si a vedomé riadenie vlastnej duševnej činnosti). Dôraz sa kladie tak na deklaratívne vedomosti (pravidlá, poučky, definície atd'.), ako aj procedurálne poznanie (spôsobilosti, zručnosti ako niečo urobit') a poznanie kontextu (vediet' kedy, kde, za akých podmienok to urobit'). Nie každý študent pozná a má vytvorené efektívne stratégie učenia sa a riešenia problémov, preto by mali pedagogické disciplíny poskytovat' tieto informácie a priestor pre ich nácvik s následným transferom do edukačnej reality. Vyučovanie stratégií býva najúčinnejšie vtedy, ked' je poskytnutý vzor kognitívnej činnosti, napr. myslením nahlas. Učitel' prezentuje myšlienkové procesy, ktoré prebiehajú v mysli tým, že premýšl'a nahlas v prvej osobe jednotného čísla (Medzinárodná akadémia vzdelávania, 2005). Halpern (1999) ponúka vlastný model vyučovania kritickému mysleniu, ktorý sa skladá z nasledovných častí, v ktorých ide o poznanie zručnosti a dispozícií pre kritické myslenie, štruktúrovaný tréning, ktorým jedinec zist'uje kedy je niektorá kognitívna zručnost' potrebná, aj v novom kontexte a metakognitívny monitoring, použitie metakognitívneho poznania na smerovanie a zlepšenie vlastného procesu myslenia a učenia sa. Zmyslom vyučovania ku kritickému mysleniu sa stáva rozvoj a podpora rôznych (meta)kognitívnych zručností a vlastností, ktoré sú pre život dnešného človek potrebné.

\section{Záver}

Ciel'om štúdie je poukázat' na teoretické východiská konceptu kritického myslenia a možnosti rozvoja jednotlivých kognitívnych zručností kritického myslenia študentov učitel'ských študijných programov. Dotazník, ktorý sme vytvorili na identifikovanie stratégií kritického myslenia a podrobili sme ho faktorovej analýze, nám umožnil zistit', ktoré stratégie a metódy považujú študenti učitel'ských študijných odborov, cviční učitelia a odboroví didaktici za dôležité a zároveň aký im prikladajú význam vo vlastnej praxi. Jednotlivé stratégie sme si kategorizovali do šiestich skupín a v príspevku riešime ich využitie a aplikovanie $\mathrm{v}$ rôznych pedagogických disciplínach. Kritické myslenie a jeho transfer považujeme v súčasnosti za významnú psychodidaktickú kompetenciu učitel'a, ktorú by mal byt' schopný preukázat', aby vedel ku kritickému mysleniu viest' aj svojich budúcich žiakov. Nie každý človek môže dosiahnut' vysokú úroveň kritického myslenia, ale môžeme ho rozvíjat' $\mathrm{v}$ rámci jeho intelektuálnych možností prostredníctvom vyučovania, či tréningu. Preto si kladieme otázku, či by sa v ponuke akademických predmetov nemalo objavit' kritické myslenie ako samostatný kurz, ktorý by obsahovo riešil daný konštrukt vo všeobecnej rovine a viedol k vytváraniu jednotlivých zručností kritického myslenia s transferom do bežných životných situácií, v ktorých človek čelí rôznym typom problémov.

Tento príspevok je výstupom APVV projektu č. 15-0368 Prax v centre odborovej didaktiky, odborová didaktika v Centre praktickej prípravy.

\section{Bibliographic references}

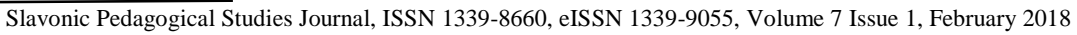


DUCHOVICOVA, J. - PETROVA, G. 2016. Personal competences of absolvents as prerequisite of social inclusion. In Slavonic Pedagogical Studies Journal: The Scientific Educational Journal, vol. 5, no. 1, pp. 184-200. ISBN 1339-8660.

DUCHOVICOVA, J. - TOMSIK, R. 2017. Critical and creative thinking strategies in teaching internal consistency of the research tool. In. Slavonic Pedgogical Studies Journal. Vol. 6, N. 2, p. 375-394.

DUCHOVICOVA, J. - FENYVESIOVA, L. - GROFCIKOVA, S. a kol. 2017. Strategie kritickeho a tvoriveho myslenia vo vyucovani. Dotaznik pre studentov. In Brecka, P. - Valentova, M. (ed.): Strategie kritickeho a tvoriveho myslenia $\mathrm{v}$ odborovych didaktikach vychovnych predmetov. Nitra : PF UKF, 169 - 174 s., ISBN ISBN 978-80-558-1227-4 .

FACIONE, N.C. - FACIONE, P. A. 2008. Critical Thinking and Clinical Judgement. In Critical Thinking and Clinical Reasoning in the Health Sciences: A Teaching Anthology. CA, Millbrae : Insight Assessment, The California Academic Press, pp. 1-13.

FACIONE, P.A. 2013. Critcal Thinking: What It Is and Why It Counts. CA: Measured Reasons and Insight Assessment [PDF]. Available at: https://www.nyack.edu/files/CT_What_Why_2013.pdf

GROFCIKOVA, S. - KOZAROVA, N. 2017. Metacognitive skills of pregraduate teacher students as a condition for development of their key didactic competences. In SGEM 2017 : 4th International Multidisciplinary Scientific Conference on Social Sciences and Arts. Proceedings Volume 2. Albena : STEF92 Technology, s. 315-321, ISBN 978-619-7408-22-5.

HALPERN, D. F. 1999. Teaching for Critical Thinking: Helping College Students develop the Skills and Dispositions of a Critical Thinker. In New Direction for Teaching and Learning, no. 80, pp. 69-74. DOI 10.1002/tl.8005. HIGGINS, S. E. 2014. Critical thinking for 21 st-century education: a cybertooth curriculum? In Prospects, no.4, pp. 559-574. Available at: http://dx.doi.org/10.1007/s11125-014-9323-0.

KRYKORKOVA, H. 2008. Autoregulace a metakognice v kontextu psychologie skolniho uceni. [PDF]. Available at: http://skolniuceni.cz/PDF\%20soubory\%20a\%20texty/ReferatZLIN.pdf

LIVINGSTON, J. A. 1997. Metacognition: An Overview. Dostupne na:https://www.researchgate.net/publication/234755498_Metacognition_An_ Overview

MAGNO, C. 2010. The role of metacognitive skills in developing critical thinking. In Metacognitive Learning, no. 5, pp. 137-156. DOI 10.1007/s11409-010-9054-4.

MEDZINARODNA AKADEMIA VZDELAVANIA. 2005. Efektivni uceni ve skole. Praha : Portal, 144s. ISBN 80-7178-556-3.

PETROVA, G. - KOZAROVA, N. 2017. Metacognitive Development of Students. In Schola 2016: Pedagogy and Didactics in Technical Education. Praha: CVTU, s. 29-34. ISBN 978-80-01-06112-1, s. 29-34.

Van GELDER, T. 2005. Teaching Critical Thinking: Some Lessons from Cognitive Science. In College Teaching, vol. 53, no. 1, pp. 41-46.

WALKER TILESTON, D. 2005. 10 Best Teaching Practices. Thousand Oaks (CA) : Corwin Press, 111p. ISBN 978-1-4129-1472-7. 
WILLIAMS, R. L. 2005. Targeting Critical Thinking Within Teacher Education: The potential Impact on Society. In The Teacher Educator, vol. 40, no. 3, pp. 163-187. Proquest Central.

PaedDr. Soňa Grofč́́ková, PhD.

doc. PaedDr. Jana Duchovičová, PhD.

doc. PaedDr. Lívia Fenyvesiová, PhD.

Katedra pedagogiky, Pedagogická fakulta

Univerzita Konštatntína filozofa v Nitre

Dražovská cesta 4

94974 Nitra

Slovakia

sgrofcikova@ukf.sk 